\title{
Parasitic Diseases of Exotic Carp in Bangladesh
}

\author{
M. Arifa AKTER ${ }^{1}$, M. Delwer Hossain ${ }^{2}$ And M. RedWANUR RAHMAN ${ }^{3 *}$ \\ ${ }^{182}$ Department of Fisheries, University of Rajshahi, Rajshahi, Bangladesh \\ ${ }^{3}$ Institute of Environmental Science, University of Rajshahi, Rajshahi, Bangladesh
}

\begin{abstract}
Five exotic carp species viz. Hypophthalmichthys molitrix, Cyprinus carpio var. specularis, Cyprinus idellus, Cyprinus carpio var. communis and Puntius gonionotus were examined for parasitic diseases out of which 793 fishes were infected by 3 protozoan (Trichodina sp., Ichthyophthirius sp. and Chilodonella sp.), 2 monogenean (Gyrodactylus sp., Dactylogyrus sp.), 2 trematoda (Gorgotrema sp., Metadena sp.), 4 cestoda (Rhopalothyrax sp., Marsipometra sp., Lytocestus sp. and Senga sp.), 2 nematoda (Camallanus sp., Procamallanus sp.), 3 crustacean (Argulus sp., Alitropus sp. and Lamproglena sp.) and 1 insect (Dipteran larvae) parasitic species. These parasites were isolated from body slime, gills and intestine of the infected fishes. In general species wise parasitic average prevalence was highest in Argulus sp. (20.07\%) in H. molitrix and lowest in Metadena sp. (2.85\%) in C. carpio var. communis. Average abundance was highest in Argulus sp. (0.70) in $\mathrm{H}$. molitrix and lowest was in Lamproglena sp. (0.04) in C. carpio var. communis. Average mean density was highest in Chilodonella sp. (10.00) in C. carpio var. specularis and lowest in Procamallanus sp. (2.08) in C. carpio var. communis.
\end{abstract}

Key words: Parasites, diseases, exotic carp.

\section{INTRODUCTION}

Diseases affect the normal health conditions and cause reduction of growth, abnormal metabolic activates and even death. It also deteriorates the normal health condition of fish and cause fish mortality, thus results great economic loss. Healthy of any population depends on the control of disease and maintenance of a healthy relationship between living creatures and their environment (Snieszko 1983).

However, five factors directly influence the parasite fauna of fishes like age, diet, abundance of fishes, independent number of a parasite within the fish and season (Kabata 1985). Srivastava (1975) stated that the characteristic of any water body can influence and determine its parasitic fauna and when environmental conditions, such as water, food and temperature become favourable for mass reproduction of parasites, the disease may spread very quickly. Hoffman (1967) suggested that the treatment or control of fish parasitic disease can be best achieved, if the approach could be made through following logical patterns: (i) identifying the parasite, (ii) obtaining a through knowledge of the life histories which may be simple or very complicated, (iii) learning the ecological requirements of the parasite, such as host specificity, optimum temperature, $\mathrm{pH}$, nutrition and other metabolic

* Corresponding author: Assistant Professor, IES, University of Rajshahi; Tel: 0721-750930; E-mail: redwan_rahman@lycos.com

(C) 2006 School of Agriculture and Rural Development, Bangladesh Open University, All rights reserved. 
requirements, (iv) mapping the geographic range of the parasite, (v) determining the effect of immunological mechanisms of the host on the parasite (vi) studying control and treatment method.

A majority of freshwater fishes carry heavy infection of parasites which cause deterioration in the food value of fish and may even result in their mortality. Besides these, there are a number of helminth parasites which are transmitted to human beings only through fish. The study of helminth parasites, its frequency and distribution in fishes, is very scant in Bangladesh, compared to the considerable progress achieved by Japan, India and other oriental regions. These parasites use the fish for their shelter and food and destruct more or less each and every organ resulting in pathogenic effects (Lilley et al. 1992). Parasites interfere with the nutrition, metabolism and secretary function of alimentary canal, damage nervous system and even upset the normal reproduction of the hosts (Rahman et al. 1998a,b). The distribution of helminths of the same host and their incidence and intensity of infestation varies from one place to another. One should know these variations in infestation and the taxonomic details of these worms for proper management of the fish crop in ponds.

The parasitic infection is greatly influenced by the season, which basically interferes with ecology and physiology of the fish. During the breeding season of fish lesser number of parasites invade the host because of the presence of the oestrogen (Rahman and Jahan 2002). The presence of certain helminth parasites, especially larval trematode is known to eliminate or reduce the reproduction in molluscs (Rahman and Jahan 2005).

Recently, Hossain et al. (1994a,b), Hafizuddin and Shahabuddin (1996), Akhter et al. (1997), Rahman, et al. (1998a,b), Parween and Rahman (2000), Banu and Khan (2004), Rahman and Parween (2001) and Alam et al. (2006) have made some attempts to explore the fauna of helminth parasites of freshwater fishes in Bangladesh.

Crustacean is an important disease producing parasite of freshwater fishes. Hoffman (1977) while describing the pathogenicity of Argulus reported that it can kill a larval eel by a single sting which injects a cytoplasmic toxin into the host. It is also reported that this parasite creates ulceration and haemorrhagic changes to the host skin providing ready access to secondary infections by other parasites, bacteria, fungi and viruses.

Though a number of information have already been reported from our water bodies. But no work has yet been done in Northwest areas of Bangladesh. The objectives of the present study are to isolated and identify common external and internal parasites and the nature of infestation of freshwater exotic fishes.

\section{MATERIALS AND METHODS}

A total number of 1431 fishes were examined of which 793 species were infected by different ecto and endoparasites from July, 2004 to June 2006. These fishes were mainly caught from the ponds of Rajshahi Metropolitan City and the adjacent beels, rivers and water bodies. The fish species comprised exotic carps like of 299, Hypophthalmichthys molitrix; 278, Cyprinus carpio var. specularis; 279, Cyprinus idellus; 281, Cyprinus carpio var. communis and 294, Puntius gonionotus. Fishes were collected month wise from different water bodies and fish landing centres of sampling areas for detection of the presence of parasites.

To find out parasites, fish was examined fresh while the parasites were still alive because their movement aids in locating and identifying them. Samples were brought to the Fisheries Research Laboratory, Department of Fisheries, University of Rajshahi, Rajshahi, in a bucket containing water. Immediate after the arrival, the total length and weight were recorded. External parasites from body surface, fin and gill were removed by scrapping the slime with a sharp scalpel in a drop of water on a clean dry glass slide and spreaded it evenly. After that a cover slip was placed over the materials. The gill arches were removed and macerated on slides and examined under a compound binocular and trinocular microscope. In case of monogeneans the gill were removed into petridishes containing water and gently scrapped to dislodge monogeneans. The monogeneans were removed on to clear slides with a fine pipette in a drop of water and covered with cover slip.

For endoparasites fishes were dissected out ventrally by a sharp scalpel to observe parasites inside buccal cavity stomach and intestine. The whole gut was removed in a watch glass containing 
$0.9 \%$ physiological saline. Then cleaned several times with tap water to free from any unwanted materials. Small worms were searched initially with the help of magnifying glass by scrapping out mucus. Worms were then collected for identification. Ecto and endoparasites were identified up to genus on the basis of available taxonomical characters as described by Yamaguti $(1958,1963)$, Hafizuddin and Shahabuddin (1996), Agarwal and Sharma (1988). After identification only metazoan parasites were preserved in AFA $(120 \mathrm{ml}$ distilled water+ $6 \mathrm{ml}$ Ethyl Alcohol+ $30 \mathrm{ml}$ Formalin+10 ml Glycerin $+0.5 \%$ neutral or methylene blue/Acetocarmine) solution for detailed study. The measurements of the parasites diameter, length, width were taken using oculo micrometer which was adjusted with stage micrometer. Diagrams were made with the aid of camera Lucida, Montex Camera.

Prevelence, abundance and mean density were estimated following the formulae proposed by Margolis et al. (1982) as:

$$
\begin{aligned}
\text { Prevalence } & =\frac{\text { Total number. of infected fishes }}{\text { Total number of fishes hosts examined }} \times 100 \\
\text { Abundance } & =\frac{\text { Total number of parasites recovered }}{\text { Total number of fish hosts examined }} \\
\text { Mean density } & =\frac{\text { Total number of parasites recovered }}{\text { Total number of infected fishes }}
\end{aligned}
$$

Level of infestation: Level of infestation was measured as follows- Low: 1 - 5 parasites / slide, Medium : 6 - 10 parasites / slide, High: more than 11 parasites / slide.

\section{RESULTS AND DISCUSSION}

The parasites were isolated from body slime/skin, gill and intestine of studied fish species. The isolated parasites from different organs of fishes were Trichodina sp., Chilodonella sp., Ichthyophthirius sp., Gyrodactylus sp., Dactylogyrus sp., Gorgotrema sp., Metadena sp., Rhopalothyrax sp., Marsipometra sp., Lytocestus sp., Senga sp., Camallanus sp., Procamallanus sp., Argulus sp., Alitropus sp., Lamproglena sp. and Dipterian larvae. Thus the three protozoan, two monogenean, two digenea, four cestode, two nematode, one branchiuran, one isopoda, one copepoda and Dipteran larvae were identified up to genus level (Table 1).

A total of seven ectoparasite species and ten endoparasite species were found from the studied species. The parasites in different organs of different exotic species are shown in Table 1.

\begin{tabular}{|c|c|c|c|c|c|c|c|c|}
\hline \multirow{2}{*}{$\begin{array}{l}\text { Sl. } \\
\text { No. }\end{array}$} & \multirow{2}{*}{ Species } & \multirow{2}{*}{$\begin{array}{l}\text { No. of fish } \\
\text { examined }\end{array}$} & \multirow{2}{*}{$\begin{array}{l}\text { No. of } \\
\text { infected } \\
\text { fish }\end{array}$} & \multirow{2}{*}{$\begin{array}{l}\text { Range of } \\
\text { total length } \\
\text { (cm) }\end{array}$} & \multirow{2}{*}{$\begin{array}{l}\text { Range of } \\
\text { total } \\
\text { weight }(\mathrm{g})\end{array}$} & \multicolumn{3}{|c|}{ Parasites in different Organs } \\
\hline & & & & & & Skin & Gill & Intestine \\
\hline 1. & H. molitrix & 299 & 159 & $27-52$ & $200-1500$ & $\begin{array}{l}\text { Argulus sp. } \\
\text { Alitropus sp. } \\
\text { Ichthyophthirius sp. }\end{array}$ & Dactylogyrus sp. & $\begin{array}{l}\text { Camallanus sp. } \\
\text { Lamproglena sp. }\end{array}$ \\
\hline 2. & $\begin{array}{l}\text { C. carpio var. } \\
\text { specularis }\end{array}$ & 278 & 156 & $14-48$ & $25-2000$ & $\begin{array}{l}\text { Trichodina sp. } \\
\text { Chilodonella sp. } \\
\text { Gyrodactylus sp. }\end{array}$ & $\begin{array}{l}\text { Gyrodactylus sp. } \\
\text { Dactylogyrus sp. }\end{array}$ & $\begin{array}{l}\text { Metadena sp. } \\
\text { Marsipometra sp. } \\
\text { Procamallanus sp. } \\
\text { Dipteran larvae }\end{array}$ \\
\hline 3. & C. idellus & 279 & 159 & $24-55$ & $250-2100$ & $\begin{array}{l}\text { Gyrodactylus sp. } \\
\text { Argulus sp. } \\
\text { Ichthyophthirius sp. }\end{array}$ & $\begin{array}{l}\text { Trichodina sp. } \\
\text { Dactylogyrus sp. } \\
\text { Gyrodactylus sp. }\end{array}$ & $\begin{array}{l}\text { Lytocestus sp. } \\
\text { Senga sp. } \\
\text { Metadena sp. }\end{array}$ \\
\hline 4. & $\begin{array}{l}\text { C. carpio var. } \\
\text { communis }\end{array}$ & 281 & 154 & $20-51$ & $100-1800$ & $\begin{array}{l}\text { Chilodonella sp. } \\
\text { Argulus sp. }\end{array}$ & Dactylogyrus sp. & $\begin{array}{l}\text { Rhopalothyrax sp. } \\
\text { Procamallanus sp. } \\
\text { Lamproglena sp. } \\
\text { Dipteran larvae }\end{array}$ \\
\hline 5. & P. gonionotus & 294 & 165 & $15-29$ & $60-300$ & $\begin{array}{l}\text { Trichodina sp. } \\
\text { Arqulus sp. }\end{array}$ & Dactylogyrus sp. & $\begin{array}{l}\text { Gorgotrema sp. } \\
\text { Senqa sp. }\end{array}$ \\
\hline
\end{tabular}

Table 1. Investigated fish species and isolated parasites in different organs during July 2004 - June 2006. 
Md. Redwanur Rahman et al.

\section{Hostwise prevalence (\%), abundance and mean density of parasites:}

During the investigation period infection, prevalence, abundance and mean density of protozoan and metazoan parasites were observed. The results are given below hostwise in Table 2.

1. $\boldsymbol{H}$. molitrix: The prevalence, abundance and mean densities were $10.03 \%, 0.50$ and 5.00 respectively of Dactylogyrus sp. The infection was medium. For Camallanus sp., prevalence, abundance and mean densities were $6.69 \%, 0.30$ and 4.50 respectively. The infection was low. $H$. molitrix were infected by Argulus sp. and its prevalence, abundance and mean densities were $20.07 \%, 0.70$ and 3.50 respectively. The infection was high. $H$. molitrix were infected by 140 Alitropus sp. The prevalence of parasite was $10.03 \%$, abundance was 0.47 and mean density was 4.67. The infection was high. Lamproglena sp., prevalence, abundance and mean densities were $6.35 \%, 0.26$ and 4.11 respectively. The infection was low (Table 2).

The seasonal monthly average prevalence of parasite in $\mathrm{H}$. molitrix was highest in January (70.00\%) and lowest in June (38.89\%), abundance was highest in January (3.30) and lowest in November (1.68) and mean density was highest in September (5.31) and lowest in November (3.23). The total number of fish $(H$. molitrix) parasites prevalence in two years was $53.17 \%$, abundance was 2.23 and mean density was 4.20 (Fig. 1-3).

2. C. carpio var. specularis: Prevalence, abundance and mean densities were $10.43 \%, 0.43$ and 4.14 respectively of Trichodina sp. The infection was medium. For Chilodonella sp., prevalence, abundance and mean densities were $15.40 \%, 0.54$ and 10.00 respectively. The infection was low. C. carpio var. specularis were infected by Gyrodactylus sp. and it prevalence, abundance and mean densities were prevalence were $7.19 \%, 0.50$ and 7.00 respectively. The infection was low. Dactylogyrus sp., prevalence, abundance and mean densities were 14.39\%, 0.45 and 3.13 respectively. The infection was high. Prevalence, abundance and mean densities were $3.96 \%, 0.22$ and 5.45 respectively of Metadena sp.. The infection was low. Marsipometra sp., prevalence, abundance and mean densities were $5.40 \%, 0.32$ and 6.00 respectively. The infection was low. Prevalence, abundance and mean densities were $3.60 \%, 0.27$ and 7.50 respectively of Procamallanus sp. The infection was low. Prevalence, abundance and mean densities were 5.76\%, 0.24 and 4.19 respectively by Dipteran larvae. The infection was low. (Table 2).

The seasonal monthly average prevalence of parasite in C. carpio var. specularis was highest in November (70.59\%) and the lowest in March (45.45\%), parasites abundance was highest in June (4.24) and lowest in April (2.38) and mean density was highest in December (6.89) and lowest in September (4.06). The total number of fish (C. carpio var. specularis) parasites prevalence in two years was 56.12\%, abundance was 2.97 and mean density was 5.30 (Fig. 1-3).

3. C. idellus: The prevalence, abundance and mean densities were $8.96 \%, 0.45$ and 5.00 respectively of Trichodina sp. The infection was medium. For Gyrodactylus sp., prevalence, abundance and mean densities were $10.75 \%, 0.50$ and 4.67 respectively. The infection was low. $C$. idellus were infected by Dactylogyrus sp. Its prevalence, abundance and mean densities $13.26 \%$, 0.57 and 4.32. The infection was medium. Lytocestus sp., the prevalence, abundance and mean densities were $7.17 \%, 0.20$ and 2.80 respectively. The infection was medium. C. idellus were infected by 63 Senga sp. and its prevalence, abundance and mean densities were $5.38 \%, 0.23$ and 4.90 respectively. The infection was low. Argulus sp. found in skin and it prevalence, abundance, mean densities were 11.47\%, 0.39 and 3.44. The infection was medium (Table 2).

The seasonal monthly average prevalence in C. idellus was highest in January (68.42\%) and the lowest in May and July (50.00\%), abundance was highest in February and May (2.89) and lowest in December (1.63) and mean density was highest in May (5.77) and lowest in December (3.06). The total number of fish (C. idellus) parasites prevalence in two years was $56.99 \%$, abundance was 2.34 and mean density was 4.11 (Fig. 1-3).

\section{C. carpio var. communis:}

C. carpio var. communis were infected by Ichthyophthirius sp., Chilodonella sp., Gyrodactylus sp., Dactylogyrus sp., Metadena sp., Rhopalothyrax sp., Procamallanus sp., Argulus sp., and 
Lamproglena sp. The prevalence, abundance and mean densities were calculated in table 2 . Gyrodactylus sp. and Argulus sp. infection were high.

The seasonal monthly average prevalence of parasite during the study period in C. carpio var. communis was highest in February (73.68\%) and the lowest in April (45.00\%), abundance was highest in February (3.26) and lowest in October (2.00) and mean density was highest in March (4.91) and lowest in June (3.41). The total number of fish (C. carpio var. communis) parasites prevalence in two years was $54.80 \%$, abundance was 2.34 and mean density was 4.27 (Fig. 1-3).

\section{P. gonionotus:}

P. gonionotus were infected by Trichodina sp., Dactylogyrus sp., Gorgotrema sp., Senga sp. and Argulus sp. and their prevalence, abundance and mean densities were present in table 2. Argulus $\mathrm{sp}$ infection was high.

The seasonal monthly average prevalence of parasite during the investigation period in $P$. gonionotus was highest in January (68.18\%) and the lowest in March (48.39\%), abundance was highest in January (3.23) and lowest in September (1.85) and mean density was highest in March (5.20) and lowest in June (3.19). The total number of fish ( $P$. gonionotus) parasites prevalence in two years was $56.12 \%$, abundance was 2.33 and mean density was 4.16 (Fig. 1-3).

Table 2. Average prevalence (\%), abundance and mean densities of parasites in different culturable exotic carp species (July 2004 - June 2006)

\begin{tabular}{|c|c|c|c|c|c|c|c|c|c|}
\hline $\begin{array}{l}\text { Sl. } \\
\text { No. }\end{array}$ & Species & $\begin{array}{l}\text { No. of fish } \\
\text { examined }\end{array}$ & $\begin{array}{c}\text { No. of fish } \\
\text { infected }\end{array}$ & $\begin{array}{c}\text { No. of } \\
\text { parasites }\end{array}$ & Isolated parasites & $\begin{array}{c}\text { Prevalence } \\
(\%)\end{array}$ & Abundance & $\begin{array}{c}\text { Mean } \\
\text { density } \\
\end{array}$ & $\begin{array}{l}\text { Mode of } \\
\text { infection }\end{array}$ \\
\hline \multirow{5}{*}{1.} & \multirow{5}{*}{ H. molitrix } & \multirow{5}{*}{299} & 30 & 150 & Dactylogyrus sp. & 10.03 & 0.50 & 5.00 & ++ \\
\hline & & & 20 & 90 & Camallanus sp. & 6.69 & 0.30 & 4.50 & + \\
\hline & & & 60 & 210 & Argulus sp. & 20.07 & 0.70 & 3.50 & +++ \\
\hline & & & 30 & 140 & Alitropus sp. & 10.03 & 0.47 & 4.67 & +++ \\
\hline & & & 19 & 78 & Lamproglena sp. & 6.35 & 0.26 & 4.11 & + \\
\hline \multirow{8}{*}{2.} & \multirow{8}{*}{$\begin{array}{l}\text { C. carpio var. } \\
\text { speculars }\end{array}$} & \multirow{8}{*}{278} & 29 & 120 & Trichodina sp. & 10.43 & 0.43 & 4.14 & ++ \\
\hline & & & 15 & 150 & Chilodonella sp. & 5.40 & 0.54 & 10.00 & + \\
\hline & & & 20 & 140 & Gyrodactylus sp. & 7.19 & 0.50 & 7.00 & + \\
\hline & & & 40 & 125 & Dactylogyrus sp. & 14.39 & 0.45 & 3.13 & +++ \\
\hline & & & 11 & 60 & Metadena sp. & 3.96 & 0.22 & 5.45 & + \\
\hline & & & 15 & 90 & Marsipometra sp. & 5.40 & 0.32 & 6.00 & + \\
\hline & & & 10 & 75 & Procamallanus sp. & 3.60 & 0.27 & 7.50 & + \\
\hline & & & 16 & 67 & Dipteran larvae & 5.76 & 0.24 & 4.19 & + \\
\hline \multirow{6}{*}{3.} & \multirow{6}{*}{ C. idellus } & \multirow{6}{*}{279} & 25 & 125 & Trichodina sp. & 8.96 & 0.45 & 5.00 & ++ \\
\hline & & & 30 & 140 & Gyrodactylus sp. & 10.75 & 0.50 & 4.67 & + \\
\hline & & & 37 & 160 & Dactylogyrus sp. & 13.26 & 0.57 & 4.32 & ++ \\
\hline & & & 20 & 56 & Lytocestus sp. & 7.17 & 0.20 & 2.80 & ++ \\
\hline & & & 15 & 63 & Senga sp. & 5.38 & 0.23 & 4.20 & + \\
\hline & & & 32 & 110 & Argulus sp. & 11.47 & 0.39 & 3.44 & ++ \\
\hline \multirow{10}{*}{4.} & \multirow{10}{*}{$\begin{array}{l}\text { C. carpio var. } \\
\text { communis }\end{array}$} & \multirow{10}{*}{281} & 20 & 100 & Ichthyophthirius sp. & 7.11 & 0.36 & 5.00 & + \\
\hline & & & 13 & 90 & Chilodonella sp. & 4.63 & 0.32 & 6.92 & + \\
\hline & & & 15 & 80 & Gyrodactylus sp. & 5.34 & 0.28 & 5.33 & +++ \\
\hline & & & 32 & 95 & Dactylogyrus sp. & 11.39 & 0.34 & 2.97 & ++ \\
\hline & & & 8 & 40 & Metadena sp. & 2.85 & 0.14 & 5.00 & + \\
\hline & & & 10 & 35 & Rhopalothyrax sp. & 3.56 & 0.12 & 3.50 & + \\
\hline & & & 12 & 25 & Procamallanus sp. & 4.27 & 0.09 & 2.08 & + \\
\hline & & & 20 & 95 & Argulus sp. & 7.12 & 0.34 & 4.75 & +++ \\
\hline & & & 10 & 45 & Lamproglena sp. & 3.55 & 0.04 & 4.50 & + \\
\hline & & & 14 & 53 & Dipteran larvae & 4.98 & 0.19 & 3.79 & + \\
\hline \multirow{5}{*}{5.} & \multirow{5}{*}{ P. gonionotus } & \multirow{5}{*}{294} & 42 & 160 & Trichodina sp. & 14.28 & 0.54 & 3.81 & ++ \\
\hline & & & 45 & 180 & Dactylogyrus sp. & 15.31 & 0.61 & 4.00 & ++ \\
\hline & & & 25 & 70 & Gorgotrema sp. & 8.50 & 0.24 & 2.80 & + \\
\hline & & & 15 & 61 & Senga sp. & 5.10 & 0.21 & 4.07 & + \\
\hline & & & 38 & 215 & Argulus sp. & 12.93 & 0.73 & 5.66 & +++ \\
\hline
\end{tabular}

Note: Low infection $=+$, Medium infection $=++$, High infection $=+++$, 
Md. Redwanur Rahman et al.

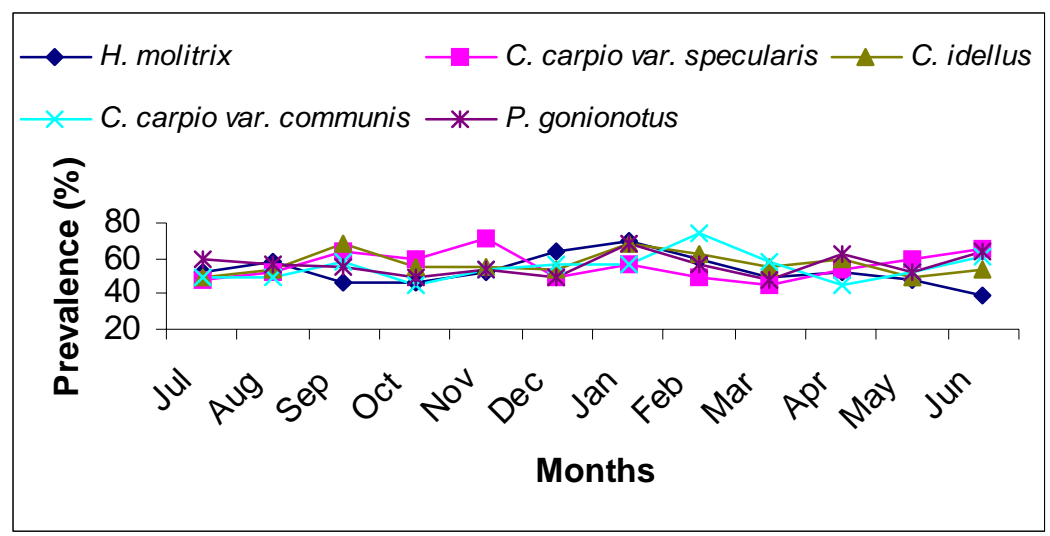

Fig. 1. Monthly average prevalence of parasites in five exotic carp species (July 2004 - June 2006)

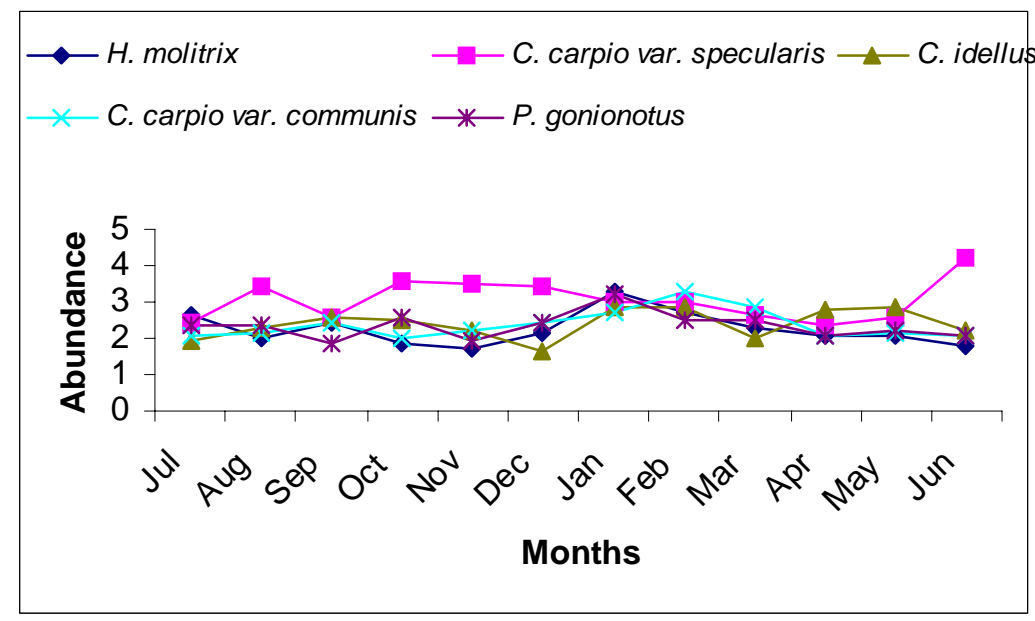

Fig. 2. Monthly average abundance of parasites in five exotic carp species (July 2004 - June 2006)

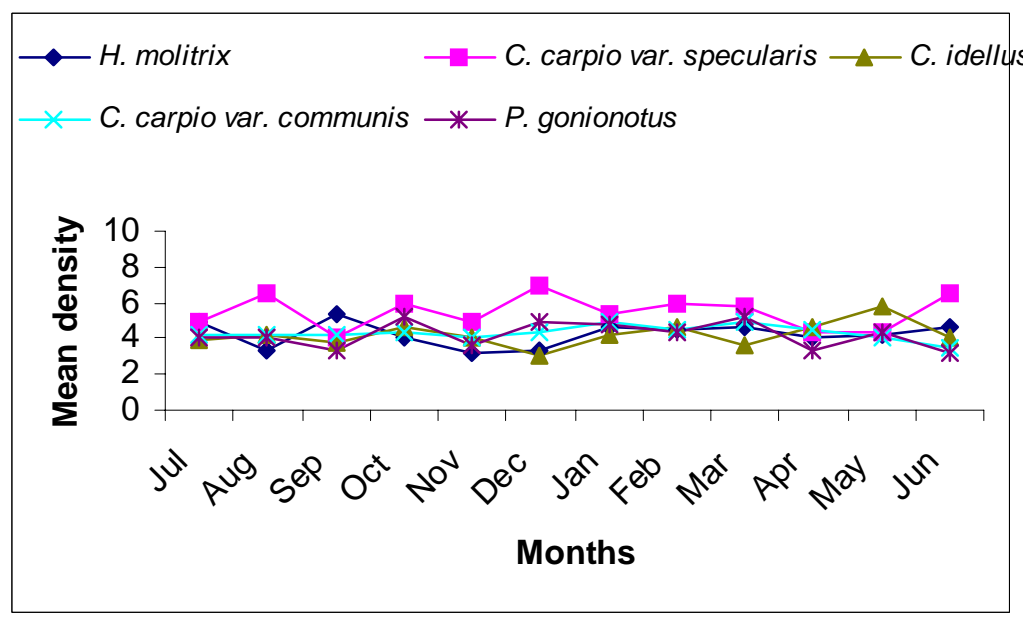

Fig. 3. Monthly average mean density of parasites in five exotic carp species (July 2004 - June 2006) 
It has been observed that infestation of different parasites in different months varied at various levels. Prevalence, abundance and mean densities of protozoan and metazoan parasites were also observed and found to vary from season to season in the present work. A total of 1431 fish samples of $H$. molitrix, C. carpio var. specularis, C. idellus, C. carpio var. communis and $P$. gonionotus were examined, of which 793 samples were infected by one or more species of ecto and endoparasites. The parasites were isolated from body slime/skin, gill and intestine in different exotic carp species. The isolated parasites were Trichodina sp., Ichthyophthirius sp., Gyrodactylus sp., Dactylogyrus sp., Gorgotrema sp., Metadena sp., Rhopalothyrax sp., Marsipometra sp., Lytocestus sp., Senga sp., Camallanus sp., Procamallanus sp., Argulus sp., Alitropus sp., Lamproglena sp. and Dipteran larvae. Whitish to yellowish cysts in the skin and gill, loss of mucus, slight haemorrhage at the base of dorsal, pectoral and caudal fin were observed in case of heavily infected fish. Subasinghe (1992) studied hatchery diseases of freshwater fish in Sri Lanka and reported heavy mortality in major carp fry and fingerlings due to ciliate ectoparasite like Trichodina sp., Ichthyophthirius sp., Chilodonella sp. and fluke like Dactylogyrus sp. during nursery operation.

It was observed that there was monthly variation in the rate of infection and infestation of parasites in fish. November to March was the most susceptible period of the year when fish parasites are abundant. This could be due to stocking density, water depth, temperature along with other physico-chemical parameters and management practices maintained (Banu and Khan, 2004). Mohan (1999) reported that ectoparasites, protozoans, monogenetic trematodes, fish lice, anchor worm, endoparasitic protozoans are some of the very important pathogens that have had significant impact on the yield in carp hatcheries and seed production centres in India. Perhaps parasite acts either as a pathogen or vector for diseases (Roberts et al. 1986). Although Reungprach et al. (1983) found no direct relationship of ectoparasite with the occurrences of dermal lesion (EUS). Hossain et al. $(1994 a, b)$ reported that highest mortality of carp fingerlings were reported from nurseries infected with Trichodina sp., Myxobolus sp. and Dactylogyrus sp.

In our present investigation, the infested exhibited monthly or seasonally fluctuation. The associated parasites with the fish species of the present study were supported by the findings of Akhtar et al. (1997) and Hossain et al. (1994a,b). From this study it has been observed that the seasonal variation of parasites existed among the studied location and also in respect of fish species investigated. Further research need to be carried out for studying parasites as well as diseases of other species in the country to depict an elaborate and full information of fish diseases of Bangladesh.

\section{CONCLUSION}

Fish diseases are the great threat in our fish culture system. Many fish species affects by various types of diseases every year and as a result, production of fishes decreases significantly in Bangladesh. Proper steps should be taken to prevent fish diseases and to protect these important fish species from extinction. From overall study it was observed that the parasites were most important pathogen for diseases outbreak. It was also observed that there was a direct relation between disease outbreak among fishes and environmental factors.

\section{LITERATURE CITED}

Agarwal, N. and Sharma, R. 1988. A new species of the monogenean genus Heteromazocraes mamaevi, 1981 , from a freshwater syprinid Securicula gora (Ham.) from the Lucknow district, India. Syst. Parassitol. 11, 5964.

Akhter, M., D'Silva, J. and Khatun, A. 1997. Helminth parasites of Anabas testudineus (Bloch) in Bangladesh. Bangladesh J. Zool. 25, 135-138.

Alam, M. M., Rahman, M.R., Huq, K.A. and Parween, S. 2006. Intensity of Helminth Parasitic Infestation in Three Freshwater Fish Species of Rajshahi. South Asian Journal of Agriculture, Agrotechnology Discipline 1(1), 1-3.

Banu, A. N. H. and Khan, M. H. 2004. Water quality, stocking density and parasites of freshwater fish in four selected areas of Bangladesh. Pakistan Journal of Biological Sciences 7(3), 436-440. 
Hafizuddin, A. K. M. and Shahabuddin, M. 1996. Parasitic monogeneans from some freshwater fishes of Comilla, Bangladesh. Chittagong Univ. Stud. Sci. 20, 113 - 126.

Hoffman, G. L. 1967. Lesions due to internal helminths of freshwater fishes. In "The Pathology of fishes" (eds. W. E. Ribelin and G. Higaki). The University of Wisconsin Press. Madison. Wisconsin, pp.151-186.

Hoffman, G. L. 1977. Argulus, a Branchuiran parasite of freshwater fishes. U. S. Fish and Wildlife Service. Fish disease leaflet. 49, 9.

Hossain, M. A., Banu, A. N. H. and Khan, M. A. 1994a. Prevalence of ectoparasites in carp nursery of Greater Mymensingh. Progress. Agric. 5(2), 39-44.

Hossain, M. A., Banu, A. N. H., Khan, M. H. and Sultana, N. 1994b. Bacterial microflora isolated from carp and catfish fry and their sensitivity to some antibiotics. Bangladesh Journal of Microbiology 11(2), 95-101.

Kabata, Z. 1985. Parasites and disease of fish cultured in the tropics. Taylore and Francis Ltd., London. 318pp.

Lilley, J. H., Philips, M. J. and Tongutai, K. 1992. A review of epizootic ulcerative syndrome (EUS) in Asia. Publ. Aquatic Animal Health Research Institute and Network of Aquaculture Center in Asia-Pacific, Bangkok, Thailand.73pp.

Margolis, L., Esch, G. W., Holmes, J. C. and Schod, G. A. 1982. The use of ecological terms in parasitology. Report of an ad-hoc Committee of the American Society of Parasitologists. J. Parasit. 68, 131-133.

Mohan, C. V. 1999. Social and economic impacts of aquatic animal health problems in aquaculture in India. Paper presented at the Aquatic Animal Health Care in Rural Aquaculture, Dhaka, Bangladesh.

Parween, S. and Rahman, M. R. 2000. Distribution of helminth parasites in different organs and their monthly rate of infection in three freshwater fishes of Rajshahi. Univ. J. Zool. Rajshahi Univ. 19, 67- 72.

Rahman, M. R., Prvez, M. A., Jahan, M. S. and Sarker, M. M. 1998a. Histopathology of Bellamya bengalensis (Lamarck) by larval helminth. Univ. J. Zool. Rajshahi Univ., 17, 19 - 27.

Rahman, M. R., Parween, S. and Ara, H. 1998b. A brief report on two helminth endoparasites from Mastacembelus armatus (Lacepede). Univ. J. Zool. Rajshahi Univ. 17, 75 -77.

Rahman, M. R. and Parween, S. 2001. Parasitic infestation in relation to length of Heteropneustes fossilis, Channa punctatus and Colisa fasciatus. Univ. J. Zool. Rajshahi Univ. 20, 53 - 56.

Rahman, M. R. and Jahan, M.S. 2002. Consequences of Larval Helminth Infecting Freshwater Gastropods. Bangladesh J. Zool. 30(2), 101-114.

Rahman, M. R. and Jahan, M. S. 2005. Larval Trematode Parasites of Freshwater Gastropods. Bangladesh J. Zool. 33(1), 13-34.

Reungprach, H., Boonyaratpalin, S., Supamatya, J., Kesornchandra, L., Polsheivin, W. and Sadvakdee, J. 1983. Special Report of the Fish Disease Outbreak Committee in Thailand. Ministry of Agriculture and Cooperative. 64pp.

Roberts, R. J., Macintosh, D. J., Tonguthai, K., Boonyaratpalin, S., Tayaputch, N., Phillips, M. J. and Millar, S. D. 1986. Field and laboratory investigation into ulcerative fish diseases in the Asia-Pacific region. Tech. Report of FAO Project TCP/RAS/4508. Bangkok, Thailand. 214 pp.

Snieszko, S. F.1983. Diseases of fishes: Research and Control. Fisheries. 8, 20-22.

Srivastava, C. B. 1975. Fish pathological studies in India: A brief review. Dr. B.S. Chauhan Comm. pp 649-358.

Subasinghe, R. P. 1992. Hatchery diseases of freshwater fish in Sri Lanka. In, Diseases in Asian Aquaculture 1 , edited by M. Shariff, R. P. Subasinghe and J. R. Arthur, Asian Fisheries Society, Philippines.

Yamaguti, S. 1958. "Systema Helminthum" Vol. I. The digenetic trematodes of vertebrates. Part I \& II. Intersciences Publishers, Inc. New York, London. 1575 pp.

Yamaguti, S. 1963. "Systema Helminthum" Vol. IV. Monogenea and Aspidocotylea. Intersciences Publishers, Inc. New York, London. 699 pp. 